\title{
Developing a Moral Behavior Learning Model Through Regular Practices at Playgroups
}

\author{
Wirdatul 'Aini \\ Nonformal Education Departement \\ Universitas Negeri Padang \\ Padang, Indonesia \\ Corresponding e-mail: wirdatul.aini@yahoo.co.id
}

\begin{abstract}
The research aimed at developing a model which could shape children's moral behavior through activities at the Playgroups in Padang. Moreover, the research was also to describe the effectiveness of the learning model that was used to shape children's moral through their regular practices. The design of the research was Research and Development using the limited test. The test design was experiment one group pretest-posttest design, without control class. Then, in terms of a wider scope, the test was given also to three more playgroups occupying with control and experiment class. The measuring indicators used were moral development, religious values, and social, emotional and independence development. The effectiveness was also described based on the teachers' observation. The data were obtained through instrument test and observation sheets. Then the data were analyzed by using t-test. The model is a combination of teaching model proposed, they are information-processing and behavioral. The information processing focuses on mastery aspect and information processing done by the students during the learning process. The findings of the research showed that the implementation of the learning model significantly shaped the children's moral, religious values, and their social and emotional development. Then according to the teachers, the implementation of the model improved children's creativity.
\end{abstract}

Keywords: learning model, building moral character children, through activities.

\section{INTRODUCTION}

The education in Indonesia aims at developing human resources. The implementation of its every stage should assist the students to gain knowledge and understand technology, to have morals, and to be skillful that, later, lead them to be a human. The curriculum developed should refer to the education constitution No. 20 the year 2003 about the national system of education. In verse 1 , it is stated that "Education is a conscious and deliberate effort to create an atmosphere of learning that learners are actively developing their own potential to be religious, to have selfcontrol and good personality, to be intelligence, and to gain skills needed in the society, nation, and state [1].

Based on what is stated in the constitution, it can be explained that the arranged education system should be able to build students' character. How the character is meant, then, is reflected in the vision and mission of any education institutions. Students, including early childhood students, should be taught since the very beginning, so that later, in their future they come to be, human with good character.

The character education for early childhood students based curriculum as stated in the school, includes morals development, religious values and social and emotional development and independence [2]. By teaching the students morals and religious values, it is expected that the students will be faithful toward the God Almighty. Teaching social development aims at helping the students to have good self-control so that they can interact with their peers, adults, and people around them. Then, the character education for students ranged from 3-4 years old includes responding to things related to religious values, morals, ability to control emotion, the students can be taught to understand religious values about how to express their deep gratitude toward Allah (dua, shalat, and sadaqoh), respects parents, and do what their parents tell them to do [3]. 
The success of learning process in order to shape the students' morals in any earlychildhood education institutions is determined by various factors, such as learning environment, students' characteristics, supports, and education policy at schools. Teachers are one major factor to gain the education goals. A creative and innovative teacher can turn learning activities into meaningful yet fun, and conducive toward the development of knowledge, personality, and morals of the students.

Based on an interview done to teachers of playgroup, it is found that there is a moral crisis among the students. Their cares toward the others are declined, they fewer respects to the elders, they are intolerant and do not follow teachers' orders. This condition occurs due to the declining of moral and religious values, social and emotional development.

In line with that, from the experience and reseach result, finds that character education in many playgroups are not as what it is expected; students are not familiar with shalat, they do not obey the orders and sometimes use hate words [4]. This shows that the students have not yet had positive character as how the society expects them to behave.

The fact that the development of morals characters has not yet been optimum may be due to the fact that teachers do not yet apply a proper learning model that can help them reach the curriculum purpose. Therefore, so that the teachers can carry out their responsibility, they need a learning model that they can use as a reference in the classroom. A model is a systematic procedure, with that procedure, the teacher can design a learning activity assisting them to reach the purpose of the lesson [5].

A character education learning model is a reference for the teachers in order to conduct teaching and learning that include moral and character development. The model of use is a combination of teaching model informationprocessing and behavioral [6]. The InformationProcessing focuses on mastery aspect and information processing done by the students during the learning process. It functions to develop students' cognitive process. The Behavioural aims to change the students' behavior. It refers to the theory of stimulusrespond and reinforcement. The combination of these two models is expected to help the students develop their skills so that they can behave in a proper acceptable way in the society.

Therefore, this research describes a learning model that combines both InformationProcessing and Behavioural. It relates to students' understanding of morals and its implementation in their daily life activities. Also, the model is tested to find its effectiveness.

\section{METHODS}

The process of designing the model referred to the steps of Research and Development (R\&D) were conducted in the two phases: uses descriptive-qualitative approach and the experiment method was used [7]. The first phase uses descriptive-qualitative approach; 1) formulating the problem, 2) conducting needs analysis, 3) collecting data and analyzing empirical findings, 4) designing the learning model to shape students' characters, 5) doing FGD, 6) revising the design, 7) validation the model, and 8) revising the model.

Furthermore, in the second phase; the experiment method was used. The test was done both limited and elaborated. The test, first, was done to Cahaya Ilahi playgroup and Al-Ikhlas playgroup using one group pretest-postest design, without control-class, each playgroup consisted of 23 children. Then, the next test was done to Al-Amin, Taruko 1 and Bahari playgroup using pretest-posttest experiment design. In each play group, there was one control-class and experiment-class. Each consisted of 30 children. The data were collected by doing interviews and observing children's behavior in their daily life. The analysis techniques used was statistics t-test.

\section{RESULT}

Based on the research findings related to the learning process in the playgroup, some literature reviews about theories of psychology, learning, teaching, and character and a Focus Group Discussion, a learning model of Information-Processing and Behavioral is designed. The model is a hypothetic model tested through quantitative approach using one group pretest-postest design without control class. Then, the model was tested again using 
experiment one group pretest-posttest design occupied with experiment and control class.

The research showed the effectiveness of the implementation of the learning model at AlIkhlas playgroup and Cahaya Ilahi playgroup. The test was done to each playgroup by giving pretest and post test. First, the pretest was given to Al-ikhlas playgroup, then the model was implemented, then the post-test was conducted. The same activity was also given to Cahaya Ilahi playgroup. The result showed that the scores for morals development at Al-Ikhlas playgroup was higher $(96.83>81.74)$, they were significantly different with the t-count $31.26>\mathrm{t}$ table 2.021. The mean score of morals character at Cahaya Ilahi playgroup was higher (96.04>76.70), and they were also significantly different with the t-count $37.99>2.02$. Thus, it is concluded that the implementation at Al-Ikhlas playgroup and Cahaya Ilahi shows effectiveness in shaping children's morals significantly.

Moreover, the test was also done by using pretest-posttest design occupied with experiment and control class. The sample was obtained from three playgroups; Al Amin, Bahari and Taruko 1. The sample was taken by considering the age of the students, and the students' background. Then, each playgroup was divided into two groups, class control A, and class control B. Each class consisted of 30 students.

The learning process was done by the teachers who had been assisted and introduced with the teaching model proposed. In experiment class, the teachers implemented the model while in the control class; the teachers conducted the class as usual. In the experiment class, the teachers involved the students actively, using various media provided, the children were given task based on the set program. While, in the control class, the teachers used media, the learning was not wellprogrammed and traditional. Once the learning process finished, the children were interviewed, and their behaviors were observed.

To see the effectiveness of the implementation, the indicators used were the description of children's behavior after the treatment had been given. The data obtained in the research were data about children's' moral including moral, religious, social and emotional development. Data about children's moral were obtained through interviews done to the children, by observing their daily behavior during teaching and learning at the playgroups. The scores of moral development at the three playgroups; Bahari, Al Amin and Taruko 1 was done by giving pretest, then implementing the model, then giving the posttest.

Based on the teachers' observation about the implementation of the model, it was found that the highest score obtained from the teachers was 97 and the lowest was 93, while the ideal score should be 104 . Based on the observation also, the effectiveness of the model done by doing regular practices was above the mean score; 3.62 .

Based on the mean score obtained by the teachers, the implementation of the learning model was in a good category. It indicates that the model may help the teachers to shape students' moral values. The learning process was implemented based on the model. It showed that the children's behavior changed positively.This proofs that the model developed provided opportunities for the students to well behave. It was due to the fact that the teachers let the students participate more actively during the learning process.

The result is in line with statements, the information-processing model and behavioral encourage the students to be more motivated to accept information from the teachers about morals, religious values and their socialemotional development which are explained through examples and have them practiced regularly [6]. This model is also oriented to the realm of the behavioral system model. The principle of the model is that a human is a selfcorrection system. A human can change the behavior when they respond to the information telling how successful their work is. Then, it is possible to say that children behave as how they are told about morals.

The strategy of the model consisted of syntax, social system, reaction principle and supports system. The systematic orders of the model consisted of five phases; preparation, accusation, elaboration, formation and integration. The phase 1; preparation was the teachers prepare to learn materials including content that related their previous and their current lesson. The teachers, here, asked the students to recall what they have studied about moral values. In the phase 2; accusation, the children were given tasks to relate series of pictures with their appropriate moral values. Phase 3, that was elaboration, the teachers 
explored the children's background knowledge and relate them to their current information; the children talked about their moral behavior that they did daily. Then, in phase 4 , that was formation, the teachers applied a method or a technique that could strengthen children's understanding; such as repetition method by giving lessons and praises. The phase 5; integration, the teachers combined various moral values that children could apply in their daily life.

During the implementation, it was seen that children and teachers relationships were closer and harmony. The teachers asked the children about what moral values that they had to do when they played with their friends. The children answered that they should not fight, they should share toys, and be tolerant. The children's social-emotional was getting more improved.

The reaction principle occurred due to the teachers' way in providing treatments for the children during teaching and learning process. The children behaved as how the teachers showed them to behave, the children used proper languages as for how their teachers used the language.

Body gestures and language influence children's psychic. Using good utterance influences children's positive reaction and vice versa. Positive reaction given by the children influences the teachers positively. It is in accordance with the principles of Total Physical Response (TPR) in her hypothesis, that treat the body well, that way it learns as well as the mind [8]. In this approach, the teachers were prepared to create the positive relationship with the children, coorperative the learning environment; teachers ask the children to do things with a good manner.

Moreover, the children's moral behavior improved positively significant after the treatmen had been given. It was because the teachers had well lesson plan, the implementation was conducted using integrated learning material which had been formulated and reflected in daily activities plan. Children's moral was developed at schools, within their families, and in the daily routines through regular practices. Regular practices can be defined as an effort to shape children's morals by doing such activities repeteadly. A regular moral practice shapes children's character. The research findings showed that children's character shaped due to the regular practices applied at an early-childhood education institution.

Theoriticaly, to shape children's moral, the teachers and the parents should be the model for the children. The teachers and the parents are expected to behave in accordance with the moral and the religious values. Children look for figures and self-identity, they tend to see their parents as the model to imitate. In line with opinion that states that children learn from their environment [9]. Therefore, it is necessary to provide good environment for children so that they are only to imitate good things. The environment includes teachers and parents as role models.

Then, the children's moral is shaped by inviting, informing and explaining to the children about morals and religious values, social and emotional. Giving information and explanation to the children are one simple and easy way. One of the functions of education is a transformation about values; religious, morals, and social-emotional [10]. During teaching and learning process, the teachers always repeatedly explained, talked about morals, religious and social emotional values; including worship to the Almighty.

Furthermore, the third way to shape the children's moral is by giving rewards to the children. Giving rewards by giving compliments psychologically provides reinforcement to the children. Compliments are a sign that the children have done expected behavior. It also encourages them to behave better. A compliment can be given both verbally and nonverbally. A verbal compliment is given by stating words or sentences, while non-verbally can be through gestures, nods, or facial expression. Compliments given by the teachers are supports for the children to learn better in order to have their morals shaped [11].

Also, the morals are influenced by the teaching strategy used by the teachers. The teaching strategy can both motivate and shape students' behavior. The teaching strategy should be concrete allowing the students to interact with the teaching materials and learning resources, it helps them to reach the intended basic competency and indicators; it is reflected in the lesson plan.

Teaching strategy should be arranged systematically so that the learning materials can be effectively and efficiently mastered by the 
students [5]. In the research, the strategy used could shape students' morals whether they were at schools or at home. The strategy implemented was interactive where the teachers built conducive communication that encouraged the children to follow all the activities. During the lesson, the children were given many opportunities to do deeds; such as dua before and after doing any work, greets, worships to the Almighty. Then, in every lesson, the children were treated to be independent. To help them to be more developed socially and emotionally, the children were taught to mutual help, and work and play together.

Then, the learning media used also influenced learning activities. In terms of scope, the media were grouped into two. First, learning media was used in a specific term where they only could be used effectively during wellplanned teaching and learning process. Second, in a wider term, the media used did not only cover complex electronic communication, but also covered simple slides, photos, diagrams, real objects, and visits.

Learning media should be able to provide 1) meaningful message for the students, 2) various learning method, 3) opportunities for the students to actively participate in various actions, 4) more interesting learning, and 5) unlimited learning score, 6) motivations to study, 7) students to grow in accordance with their interests and talents, 8) direct interaction with the environment, 9) stimuli to have more experiences [5].

In the research, learning media used by the teachers were media that stimulated children to act more active. They were concrete that the children could observe. The media had been set in line with the purpose of teaching and learning. In the research, the media helped the teachers to shape children's morals, religious and social emotional values. The media were character media designed based on the theme and sub-theme of the lesson.

The learning evaluation was done during and after the teaching and learning process. The evaluation should consider the following principles; 1) providing opportunities for the children to have self-evaluation, 2) the teachers should invite the students to evaluate the learning outcomes which are set based on the learning criteria [3]. The evaluation did in the research was in form of non-test. It was due to the fact that morals were observed daily at schools.

Referring to the elements and series of learning activities in class, some possible statements made were; first, the model designed could motivate and encourage the children to be actively involved in the learning process. Each activity set could help the children to follow the learning steps systematically. The children were used to have doa before and after doing the acts, they greeted and they studied better with a good manner.

Second, the learning model provided chances to have good communication between the children and the peers, and the children and the teachers. This model assisted children to do the activities in order to shape their morals. The teachers' questions were well responded by the children, and they had equal opportunity to interact with the teachers. In the class, it was seen that the children showed respects among their peers and the teachers.

Third, the learning model also let the children developed their independence. The children could work alone and finished the task given by the teachers. The dependency of the children toward the teachers' assistance was declined. Then, the children started to be responsible for the work they had.

Fourth, the media used during the learning process stimulated the children's curiosity, they were eager to know what pictures were displayed. The children were eager to participate telling the teachers what they thought about the pictures. The pictures were about children's morals. Generally, the children could deliver the moral messages contained in the pictures. Using media in the classroom has always influenced students' behavior. Learning media plays important role in motivating students to learn better, it provides opportunities for the students to directly interact with the environment [5].

Fifth, the learning media developed helped the teachers to be able to select an appropriate teaching strategy in order to integrate morals in the lesson. The selected strategy related to the approach in managing the class systematically, so that the children mastered the lesson both effectively and efficiently. In the research, it was seen that teachers used an appropriate strategy. The children were motivated, they actively participated, and they worked creatively in the class. Learning strategies are combination 
of orders, the organization of the lesson, learning tools, and time-management [5].

Sixth, the learning model developed focused on how the teachers evaluated the learning process. Evaluation is an effort to obtain various information routinely and continuously about how the process is conducted and how far the learning outcomes are achieved. In the evaluation, the teachers gathered information about the children's achievement from test and non-test; observing the children's behavior and interviewed them about their activities at the school.

\section{DISCUSSION}

The learning model to shape the children's moral behavior through regular practices through by combining Information-Processing and Behavioural model. This model helped the teachers to integrate moral lessons in the teaching and learning process. The test was done to two playgroups, and both showed significant differences in terms of pretest and posttest result. Similarly, the test was done to the other three playgroups; occupying control and experiment class were significantly different.

The teaching strategy consisted of, respectively, social system, reaction principle and supports system. The orders of this learning model consisted of five phases; preparation, accusation, elaboration, formation and integration. The learning model developed was found to be effective because it could apply various effective and innovative learning principles that optimized children's involvement and was responsive toward children's' needs.

Based on the research findings and discussion, some possible suggestions were proposed. First, the success of learning activities at playgroups was determined by the teachers, the teachers should apply the model of Information-processing and behavioral. This model helped the teachers to shape children's moral behavior by regular practices and was effectively tested. Second, the managers, the headmasters of the playgroups were expected to provide a chance for the teachers to conduct teaching and learning process that was based on the model and facilitated them the learning media and tools.

\section{REFERENCES}

[1] Undang-Undang Sisdiknas Nomor 20 tahun 2003: Jakarta: Fokus Media, p. 95, 2005.

[2] Sujiono, Nurani. (2005). Мепи Pembelajaran Anak usia Dini. Jakarta: yayasan Citra Pendidikan Indonesia, pp.115-200.

[3] Sjarkawi. (2008). Pembentukan Kepribadian Anak. Jakarta: Bumi Aksara, pp. 37-41.

[4] Yuhelmi. (2014). Pendidikan Karakter Anak Usia Dini Melalui Strategi Mendongeng. Jurnal Ilmiah Pedagogi FIP UNP. XV (2) 55-61.

[5] Trianto. (2010). Mengembangkan Model Pembelajaran Tematik. Jakarta: PT Prestasi Pustakaraya, pp. 74-78.

[6] Joyce. b \&Weil, M. (1994). Models of Teaching. New Jersey: Practice-Hall, Inc, pp. 213-230.

[7] Richey, Rita $C \&$ \& Klein, James D. (2007). Design and Development Research Lawrence Eribaum Associates Inc: New jersey, pp. 178-190.

[8] Wikanengsih. (2013). Model Pembelajaran Neorolinguistic Programming Beroeientasi Karakter bagi Peningkatan Kemampuan Menulis Siswa SMP. Jurnal Ilmu Pendidikan Malang, 19 (2): 177-186.

[9] Montessori, Maria, dkk. (2013). Pengembangan Model Pembelajaran Antikorupsi di Sekolah Menengah Atas. Kota Padang. UNP Padang, pp. 81-90.

[10] Tirtarahardja, Lasulo. (1994). Pengantar Pendidikan. Jakarta: Direktorat Jendral Pendidikan Tinggi, pp. 177-180.

[11]Rusman. (2011). Model-Model Pembelajaran (Mengembang-kan Profesioname Guru). Jakarata: Rajawali Press, pp. 84-85. 